\title{
Uma Contribuição para Aquisição de SEgunda Língua: Auxiliares e Pronomes Partitivos em Italiano E Francês
}

\author{
(A Contribution to Second Language Acquisition: Auxiliaries \\ and Partitive Pronouns in Italian and French)
}

\author{
Carlos Miото* \\ (Universidade Federal de Santa Catarina) \\ Maria Cristina Figueiredo SiLVA** \\ (Universidade Federal de Santa Catarina)
}

\begin{abstract}
This paper aims at building a bridge between theoretical linguistics, especially generative grammar, and applied linguistics, focusing on second language pedagogy as applied to the teaching of Italian and French to Portuguese- (and Spanish) speaking students. Our claim is that the generative theory's understanding of the unaccusativity phenomenon can shed light on some aspects of second language acquisition. As will be shown, this would allow students of Italian and French to internalize and comprehend the rules that govern selection of auxiliary verbs in active tenses, as well as of the distribution of partitive pronouns.

KEY-WORDS: generative grammar; second language acquisition; unaccusativity; French and Italian.
\end{abstract}

RESUMO: Este artigo objetiva construir uma ponte entre lingüística teórica, em particular teorias de cunbo gerativista, e lingüistica aplicada, em especial a pedagogia de ensino de segunda língua aplicada ao ensino de italiano e ao francês para falantes nativos de português (e espanhol). Nossa sugestão é que o conhecimento teórico gerativista do fenômeno da inacusatividade nos permite esclarecer aspectos do processo de aquisição de segunda lingua. Como mostraremos, esse conhecimento pode auxiliar alunos de italiano e francês

* Bolsista de Produtividade Ic CNPq, processo número 300557/2005-1.
** Bolsista de Produtividade II CNPq, processo número 312303/2006-8.

D.E.L.T.A., 23:esp., 2007 (243-281) 
na compreensão das regras que regem seja a seleção de verbos auxiliares nos tempos ativos seja a distribuição do pronome partitivo nestas línguas.

PALAVRAS-CHAVE: gramática gerativa; ensino de segunda língua; inacusatividade; Francês e Italiano.

\section{Introdução}

Nosso objetivo neste estudo é fazer uma ponte entre a lingüística teórica e a lingüística aplicada, em particular no que diz respeito à compreensão do funcionamento, ao ensino e à aprendizagem de línguas. Normalmente, pensa-se que existe um abismo entre esses tipos de conhecimentos. Por um lado, acredita-se que os "teóricos" estão interessados (quase) exclusivamente na tarefa de procurar construir a melhor teoria para abordar aspectos do comportamento das línguas. Aparentemente eles estão interessados apenas em fazer, desfazer e refazer a teoria a cada nova evidência empírica ou a cada insight sobre a melhor forma de explicar, nos termos da teoria com que trabalham, um determinado fenômeno. Por outro lado, acredita-se que os "práticos" estão interessados, sobretudo, em aprender e implementar técnicas que visam incrementar o aprendizado. $\mathrm{O}$ que aparentemente lhes interessa é manter os aprendizes motivados e, por conta da premência de sua atuação, o custo de aprender uma teoria lingüística é muito alto. E, tendo em vista que o que deve ser ensinado/aprendido é a língua como um todo, o custo é tanto maior porque implica aprender teorias (parciais) de cunho fonológico, morfológico, sintático, etc.

A ponte a ser construída aqui procura ligar a sintaxe gerativa e o ensino de italiano e francês (a alunos brasileiros), em particular da parte da gramática que diz respeito à seleção de auxiliares e ao uso de um certo tipo de pronome quando está em jogo um conjunto particular de verbos. Em gramática gerativa, este fenômeno é conhecido como inacusatividade. Uma das principais conseqüências das pesquisas sobre inacusatividade foi estabelecer que os verbos monoargumentais ou ditos intransitivos, que antes eram concebidos como membros de uma única classe, constituem na verdade duas classes perfeitamente distintas. Uma das classes (que doravante vamos rotular de verbos inergativos), que exemplificamos com o verbo trabalhar, se caracteriza por ter seu único argumento identificado como o argumento externo (AE), (Não tem sentido o comentário) com propriedades 
semelhantes às do sujeito dos verbos transitivos; a outra (rotulada de verbos inacusativos), que exemplificamos com o verbo chegar, tem o único argumento identificado como o argumento interno (AI), com propriedades semelhantes às do objeto dos verbos transitivos.

Durante os anos oitenta, com os trabalhos dentro da teoria gerativa, avançaram significativamente os conhecimentos sobre a inacusatividade, um fenômeno que a sintaxe das línguas naturais reflete de modo muito intrigante (o estudo de Burzio (1986) é um dos mais abrangentes sobre o assunto). Estes reflexos podem ser observados em níveis amplos como o da tipologia lingüística ou em níveis mais restritos como o das (micro-)variações entre línguas com estreito parentesco. ${ }^{1}$

No nível tipológico, as línguas são classificadas como ergativas ou nominativas de acordo com o modo como sua sintaxe reflete o fenômeno da inacusatividade. ${ }^{2,3}$ Nas línguas nominativas, a diferença na classe de verbos monoargumentais fica obscurecida: se um verbo tem apenas um argumento (não importa que seja como trabalhar ou chegar), este vai acabar como sujeito da sentença, sendo marcado por Caso Nominativo de modo paralelo ao que acontece com o AE dos verbos transitivos. ${ }^{4}$ Por sua vez, as línguas ergativas mantêm claramente a distinção entre as duas classes de verbos monoargumentais: o argumento dos inacusativos, como chegar, é o objeto da sentença, sendo marcado invariavelmente por caso absolutivo de modo paralelo ao que acontece com o AI dos verbos transitivos; o argu-

\footnotetext{
1 Deve-se frisar, no entanto, que o grau de generalidade com que se observa o fenômeno varia de língua para língua, o que equivale a dizer que é possível que certos itens lexicais que se comportam de uma forma em uma língua se comportem de outra forma em uma língua diferente (mesmo que estreitamente aparentada). Neste artigo, desconsideraremos casos isolados e trataremos o fenômeno com o maior grau possível de generalidade. Quando isso não for possível, explicitaremos o problema no corpo do texto ou em nota.

2 Os casos nominativo e acusativo das línguas nominativas são a contraparte dos casos ergativo e absolutivo das línguas ergativas. Como muitas vezes acontece na literatura, para evitar confusão usamos o termo derivado inergativo em vez de intransitivo (ou intransitivo verdadeiro) para a classe de verbos cujo único argumento corresponde ao $\mathrm{AE}$.

3 Tipologias mistas devem aqui ser desconsideradas.

4 Em línguas com morfologia rica, é a morfologia casual que estará presente. No entanto, é possível mostrar que em línguas sem morfologia casual, o papel da morfologia é exercido por outro recurso sintático. Por exemplo, é a ordem dos elementos na sentença que nos faz crer que, para além do caso morfológico, é possível pensarmos na existência de um mecanismo de marcação de Caso abstrato, uma propriedade partilhada por todas as línguas. Voltaremos a esse ponto mais detidamente na seção 2.3.
} 
mento dos verbos inergativos, como trabalhar, por sua vez, é marcado por caso ergativo de modo paralelo ao que acontece com o $\mathrm{AE}$ dos verbos transitivos. Assim, o único argumento dos verbos monoargumentais nessas línguas apresenta marcas casuais distintas dependendo do tipo de verbo monoargumental (inacusativo ou inergativo).

Também no nível mais restrito das línguas com forte parentesco, a inacusatividade produz diferenças sintáticas que estão muito longe da trivialidade, o que pode ser observado se comparamos, no domínio das línguas românicas, o italiano e o francês com o português e o espanhol. No italiano, por exemplo, quando se trata de formar o passado composto, o fato de o verbo ser inacusativo o leva a ser combinado com o auxiliar essere (ser); um verbo inergativo, por outro lado, é combinado com o auxiliar avere (ter). Inverter esta combinação, leva a sentença à agramaticalidade (representada pelo asterisco no início da sentença), como mostra (1) abaixo:

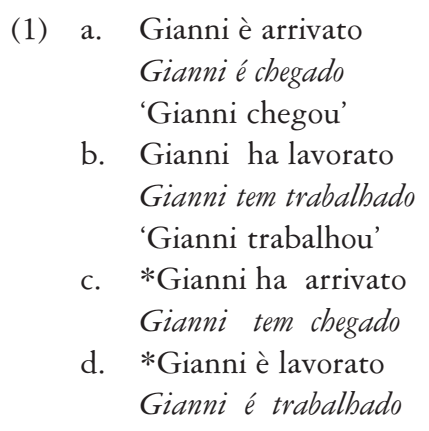

O mesmo se pode observar em francês: o passado composto de um verbo inacusativo se faz com o auxiliar être (ser), ao passo que o de um verbo inergativo se faz com o auxiliar avoir (ter):

(2) a. Jean est arrivé

Jean é chegado

'Jean chegou'

b. Jean a travaillé

Jean tem trabalhado

'Jean trabalhou'

c. *Jean a arrivé

Jean tem chegado

d. *Jean est travaillé

Jean é trabalhado 
O português ou o espanhol, por outro lado, não mostram nenhum tipo de efeito desta natureza quando se trata de combinar o auxiliar com um verbo inacusativo ou inergativo para formar o passado composto (ou o pretérito mais que perfeito composto): ${ }^{5}$ apenas a combinação com o auxiliar ter (ou haver) em português ou haber em espanhol é possível, sendo impossível a combinação com o auxiliar ser. Por isso, ao aprender italiano ou francês, um brasileiro (ou um espanhol) vai encontrar muitas dificuldades para saber com quais verbos se usa qual auxiliar; também vai encontrar dificuldades para saber com quais verbos monoargumentais é possível usar o pronome partitivo ne no italiano ou en no francês (que poderiam ser traduzidos grosseiramente por deles).

Nossa intenção aqui é, através da descrição e da explicação do fenômeno, discutir como a teoria proposta pela gramática gerativa pode contribuir para tornar o ensino/aprendizado do italiano e do francês mais eficiente.

Este artigo se organiza da seguinte forma: na seção 1, apresentamos os pressupostos formais da teoria gerativa em sua versão Regência e Vinculação, um passo necessário para que seja possível, na seção 2, apresentarmos a hipótese da inacusatividade. Finalmente, a seção 3 discute os fatos das línguas que estamos abordando, seja os de seleção de auxiliares, seja os da distribuição do pronome clítico ne do italiano e en do francês. A seção 4 está reservada para as conclusões.

\section{Pressupostos}

\subsection{A estrutura da sentença}

A gramática tradicional tem o verbo como o elemento mais importante da sentença. No entanto, é fato que uma sentença com um verbo não

\footnotetext{
5 Por achar irrelevante para esta discussão introdutória, desconsideramos o fato de o português não ter realmente um passado composto. Nesta língua, a combinação do presente do indicativo do verbo ter com um particípio passado é agramatical em contextos de iteração definida, restrição que não se observa com o passado simples do português (nem com o passado composto do italiano ou do francês):
}

(i) a. *Maria tem gritado duas vezes por socorro

b. Maria gritou duas vezes por socorro 
conjugado, no infinitivo por exemplo, não pode ser considerada propriamente uma sentença.

Estudos de sintaxe dos últimos anos (ver Koopman \& Sportiche, 1991) assentaram que há dois constituintes maiores que compõem uma sentença canônica declarativa. Um é de natureza funcional e responde por informações gramaticais (número, pessoa e caso) e semânticas (tempo, modo, aspecto) que são expressas pela flexão verbal. ${ }^{6}$ Este constituinte, que se abrevia IP (do inglês Inflection Phrase), domina um VP (do inglês Verb Phrase), que é de natureza lexical e que responde pela "cena" expressa pelo verbo e seus argumentos. Representando os dois constituintes em árvore, teríamos (3):

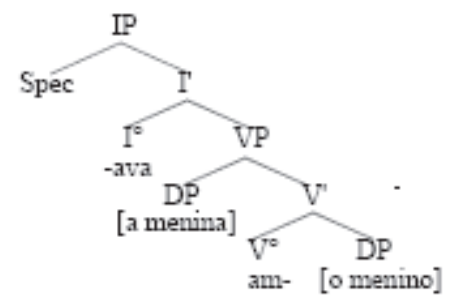

Apontamos algumas informações relevantes que estão embutidas em (3) (para mais detalhes ver Mioto et alii 2004). Cada constituinte tem três níveis de projeção, ou seja, para o IP temos $\mathrm{I}^{\circ}$, I' e IP e para VP temos $\mathrm{V}^{\circ}$, V’ e VP. O nível “”” (zero) é preenchido pelos itens (núcleos) que retiramos do nosso dicionário mental - por exemplo, o afixo /-aval que vale pelo pretérito imperfeito do indicativo e o radical /am-/ que dita que a cena em questão é de amor, cena que se compõe com dois figurantes (argumentos). No nível ' (linha), o núcleo é combinado com o complemento (argumento interno - AI): o complemento de $\mathrm{I}^{\circ}$ é o VP e o de $\mathrm{V}^{\circ}$ é o DP (Determiner Phrase) preenchido pelo sintagma o menino. O AI nesta cena é o que desempenha o papel temático (ou papel semântico) do que é amado. No nível $\mathbf{P}$, que é o nível máximo, combina-se o constituinte formado no nível linha

\footnotetext{
6 Esta é uma maneira bastante especial de conceber a morfologia verbal, muito distinta da utilizada pela gramática tradicional, que vê a morfologia verbal como parte integrante (de forma indissolúvel) do verbo, com uma relação muito mais tênue com a sintaxe. $\mathrm{Na}$ abordagem que estamos apresentando aqui, ainda que em termos morfológicos propriamente ditos a flexão e o radical verbal componham um único e inseparável item lexical, em termos sintáticos estes elementos são independentes.
} 
com um especificador (Spec): o Spec de IP é a posição que canonicamente vai ser ocupada pelo sujeito da sentença (marcado por caso nominativo), elemento que vai estar concordando com a flexão I; o especificador de VP é o $\mathrm{DP}$ preenchido por a menina. $\mathrm{O} \mathrm{AE}$ nesta cena é o que desempenha o papel temático do que ama.

O que (3) faz é analisar a sentença em seus constituintes. A pronúncia da sentença que (3) analisa requer, ${ }^{7}$ em primeiro lugar, que o radical do verbo se junte ao afixo para formar amava, já que morfemas presos como esses não podem ser pronunciados em separado; e, em segundo lugar, requer que a menina apareça antes do verbo flexionado, como mostra (4a). Se imaginamos que isso se faz através de movimentos dos constituintes para posições superiores na árvore, então (3) deve se tornar (4b) para ser pronunciada:

(4) a. A menina amava o menino

b.

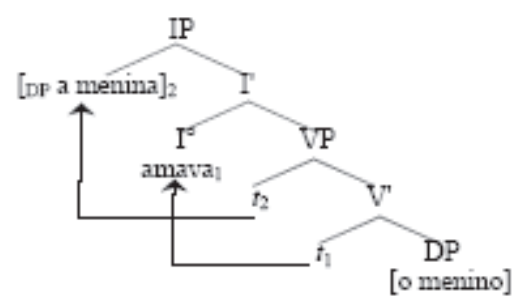

Em (4b), o símbolo $t$ (abreviação do termo trace em Inglês - vestígio em Português) marca o lugar de onde o constituinte foi movido e o índice subscrito ' 1 ' ou ' 2 ' marca qual constituinte foi movido. Chamamos (a menina $\left._{2}, t_{2}\right)$ e $\left(\right.$ amava $\left._{1}, t_{1}\right)$, que resultaram do movimento, de cadeia. A razão para este formalismo ficará clara ao longo deste estudo.

Observe que o movimento do verbo para I ${ }^{0}$ é obrigatório por questões morfológicas, mas não é clara qual seria a motivação para o movimento do DP a menina para [spec. IP]. Voltaremos a isso na seção 2.3.

\footnotetext{
7 Por hipótese, pronunciar uma sentença é tomar os constituintes de uma árvore como (4b) e, começando de cima para baixo e da esquerda para a direita, ordená-los linearmente.
} 


\subsection{A Estrutura argumental do verbo}

A sintaxe sempre se preocupou em estabelecer como se compõe a cena descrita pela sentença. Terminologia à parte, o que é comum a muitas teorias da sintaxe é que os "figurantes" entram em cena ou como argumento ou como adjunto. Os argumentos são constituintes que concorrem para compor minimamente a cena, ou seja, sem um deles a cena não se completa. O que existe além deles é incorporado como adjunto. Para o presente estudo, fundamental é a noção de argumento.

Os verbos selecionam seus argumentos de acordo com seu valor semântico (por isso dizemos que o verbo $s$-seleciona um agente, um tema, um experienciador, etc.) e/ou de acordo com sua categoria lexical (neste caso dizemos que o verbo $c$-seleciona um DP (e.g. 'o menino') um PP (do inglês Prepositional Phrase) ( e.g., 'do menino'), um CP (do inglês Complementizer Phrase) (e.g., 'que o menino ama a menina'), um IP (e.g., 'amar a menina'). As propriedades de seleção permitem enquadrar os verbos em duas classes: a dos verbos lexicais que s-selecionam e c-selecionam seus argumentos, como faz o verbo beber em (5); e a dos verbos funcionais (auxiliares) que apenas c-selecionam seus argumentos, como faz o verbo estar em (6).

(5) a. O menino bebeu o suco

b. *O menino bebeu o bife

(6) a. O menino está nadando

b. O menino está pensando

c. *O menino está pensar

A anomalia de (5b) mostra que o verbo beber não aceita como AI o bife, já que este DP é privado da propriedade semântica de ser [+líquido]. Por sua vez, o verbo estar não reage ao fato de estar combinado com um gerúndio de um verbo que expressa atividade física como nadando em (6a) ou mental como pensando em (6b); mas reage se o seu complemento é da categoria infinitivo, como vemos em (6c).

Tradicionalmente se considera que o número de argumentos de um verbo lexical pode variar de nenhum a três, de acordo com os desenhos em (7): 
(7)
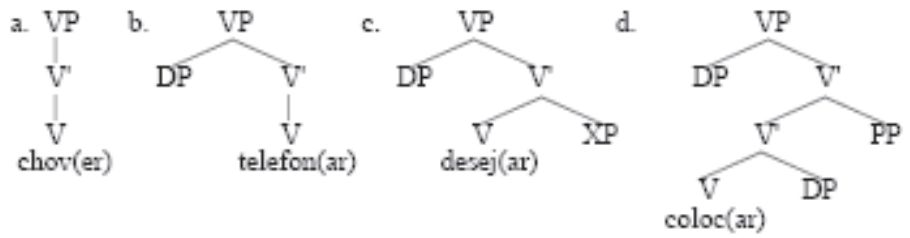

Para facilitar, estamos supondo que, se um verbo tem AE, este é da categoria DP e é sempre s-selecionado; quanto ao AI, não se pode prever a qual categoria ele pertence (por isso XP em (7c)) e nem se ele será s-selecionado ou não: como vimos no caso do auxiliar estar em (6), não há sseleção. O AI do verbo desejar, por exemplo, pode ser um DP, ou uma sentença finita $\mathrm{CP}$, ou ainda uma sentença com verbo no infinitivo, como podemos ver em (8):

(8) a. João deseja $\overleftarrow{L}_{\mathrm{DP}}$ uma maçã $]$

b. João deseja $E_{\mathrm{CP}}$ que Maria suma]

c. João deseja $\left[_{\text {InfP }}\right.$ comer uma maçã $]$

O que não é considerado pela tradição é que um verbo possa ter apenas um argumento e que este argumento seja o AI, ou seja, não é admitida pela gramática tradicional a existência de verbos inacusativos. Se admitimos a sua existência, supondo que um representante desta classe é parecer, o desenho resultante seria (9):

(9)

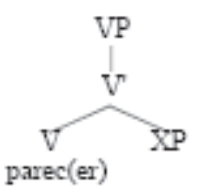

Em (9) está mantida a impossibilidade de determinar previamente qual a categoria do AI. Admitir a existência de um verbo com tal estrutura argumental é fundamental para discutir o fenômeno da inacusatividade.

Para entender a estrutura dos verbos funcionais, retomemos duas afirmações importantes: a primeira é que o AE é sempre s-selecionado; a segunda é que o AI nem sempre é s-selecionado. Assim, um verbo funcional, que não tem a capacidade de s-selecionar, nunca pode ter um AE. Por 
outro lado, ele pode (c-)selecionar um AI. Portanto, um verbo funcional só pode figurar num desenho como (9) - ou seja, a classe dos verbos inacusativos engloba um grupo de verbos lexicais e todos os verbos funcionais.

\subsection{Posições sintáticas e sua interpretação}

Quando discutimos a organização hierárquica da sentença, não dissemos nada sobre o que obriga o movimento do DP gerado em Spec VP em (4) para a posição Spec IP. Para abordarmos esta questão, vamos retomar alguns pontos do início do texto.

Quando falamos de línguas nominativas ou línguas ergativas, estamos falando de uma tipologia que foi estabelecida a partir de línguas que possuem um sistema morfológico de casos. Assim, as marcas morfológicas nos DPs que compõem uma sentença nos indicam a função gramatical daquele sintagma. Repare que desta forma estamos conectando interpretações - os papéis semânticos que discutimos na seção anterior - às funções gramaticais.

Mas não é só por meio de morfologia casual explícita que se faz a conexão entre semântica e sintaxe. A ordem das palavras no português, no francês ou no italiano responde igualmente por isso. Em português, por exemplo, em uma sentença sem entonação especial o sintagma que precede o verbo flexionado deve ser o sujeito da sentença e o que segue o verbo é o seu objeto. É por isso que em gramática gerativa falamos de uma propriedade, válida para todas as línguas, que é o Caso abstrato - revelado nas línguas pela morfologia casual visível ou pela ordem das palavras. O fundamental é que todos os DPs da sentença tenham seu Caso abstrato, pois só assim será possível estabelecermos qual é a sua função sintática e qual é a interpretação que ele deve receber.

A idéia é que a flexão finita (ou pelo menos a flexão que apresenta marcas de pessoa e número) é capaz de marcar com Nominativo o sintagma que ocupa a posição Spec IP. Por outro lado, o sintagma que segue o verbo em português nas construções transitivas é marcado com Caso Acusativo, atribuído pelo próprio verbo. Para os nossos propósitos aqui, basta falarmos desses dois Casos, chamados Casos estruturais porque dependem fundamentalmente da posição que os sintagmas ocupam na estrutura e de certas características de seus atribuidores - a flexão deve ser finita para 
atribuir Nominativo, o verbo deve ser transitivo para atribuir Acusativo. Tendo em mente estes pressupostos, vamos passar propriamente à análise dos verbos inacusativos.

\section{Verbos inacusativos}

\subsection{Demonstração}

A gramática tradicional, por entender que seu objeto de análise é apenas a sentença tal como é pronunciada, não lida com a idéia de que existem verbos cujo único argumento é um objeto, ${ }^{8}$ tal como o verbo parecer representado em (9). Para rebater esta tradição, que é bastante arraigada, podemos demonstrar que a estrutura em (9) é plausível. A demonstração vai conter dois passos principais: um deles é mostrar que o verbo parecer pode figurar em uma sentença sem que ela apresente sujeito temático, o que leva à conclusão de que este verbo não tem $\mathrm{AE}$; o outro passo é negar que, quando o verbo parecer tem um DP sujeito, este constituinte é seu AE. Recordemos que ser sujeito não é a mesma coisa que ser AE: existem sujeitos que são AIs. Por outro lado, ser AE implica ser sujeito já que, na presença de AE, se algum DP vai acabar na posição de Spec de IP, este tem que ser o $A E$.

Comecemos considerando (10), onde contrastamos parecer com o verbo transitivo desejar:

(10) a. Parece que a Maria tem muitos amigos

b. *Deseja que a Maria tenha muitos amigos

O modo mais direto de encarar o par em (10) é dizer que, se desejar não é combinado com um sujeito, a sentença é agramatical, como mostra (10b). Esta exigência, porém, não se verifica em (10a). Por outro lado, se acrescentamos um sujeito para cada um dos verbos, os julgamentos de gramaticalidade são revertidos:

8 Exceto em certas sentenças com os verbos ter e haver que são classificadas como "sem sujeito":

(i) a. Há uma gota de sangue em cada poema

b. Tinha uma pedra no meio do caminho 
(11) a. *O João parece que a Maria tem muitos amigos

b. O João deseja que a Maria tenha muitos amigos

O sujeito exigido pelo verbo desejar em (11b) não é tolerado pelo verbo parecer em (11a). Concluímos de (10) e (11) que parecer não tem AE (nem tem que apresentar um sujeito) enquanto desejar tem que ter.

Não escapou da argúcia do leitor que a afirmação anterior leva a um impasse ao consideramos (12), onde tanto desejar como parecer têm sujeito e nenhum contraste é verificado:

(12) a. A Maria parece ter muitos amigos

b. A Maria deseja ter muitos amigos

A única forma de descartar (12) como contra-argumento é mostrar que $A$ Maria não é o AE do verbo parecer ainda que seja o seu sujeito. Para dar esse passo, devemos nos lembrar que se um verbo seleciona um $\mathrm{AE}$ então ele s-seleciona este $\mathrm{AE}$, isto é, pesa sobre o que acaba sendo o sujeito da sentença uma série de restrições de cunho semântico. Se um verbo não seleciona $\mathrm{AE}$, então ele não vai reagir às propriedades semânticas daquilo que figura como seu sujeito. Assim, quando se trata de desejar, só DPs marcados pelo traço semântico [ + humano] podem acabar sendo seu sujeito; quando se trata de parecer, por outro lado, observamos que DPs com as mais variadas propriedades semânticas podem figurar como sujeito, o que é o mesmo que dizer que parecer não faz qualquer tipo de seleção (e, portanto, não impõe qualquer tipo de restrição) com respeito a este DP.

Reconsideremos (12) onde tanto desejar como parecer aceitam o DP a Maria como sujeito e o comparemos com os pares em (13) - (16):

(13) a. ?O cachorro deseja flutuar

b. O cachorro parece flutuar

(14) a. *A pedra deseja flutuar

b. A pedra parece flutuar

(15) a. *A esperança deseja ter acabado

b. A esperança parece ter acabado

(16) a. *Deseja estar chovendo sobre Santiago

b. Parece estar chovendo sobre Santiago 
O que se observa é que, se o sujeito de desejar sai da esfera do [ + + humano], a sentença apresenta anomalias semânticas. Por sua vez, o verbo parecer se combina indiscriminadamente com sujeitos de qualquer tipo semântico: pode ser humano em (12a), não-humano em (13b), inanimado em (14b), abstrato em (15b) ou pode mesmo ser o caso de uma sentença sem sujeito em (16b). Especialmente em (16b), percebemos claramente que a falta de sujeito deve ser atribuída ao verbo meteorológico chover e não a parecer (ou estar). Já que não há reação ao DP que vem a ser seu sujeito, concluímos que o sujeito de parecer não é um argumento selecionado por ele e muito menos seu $\mathrm{AE}$, pois se um argumento é selecionado, não pode ser de qualquer tipo semântico.

Finalmente, examinemos um último possível contra-exemplo para a tese de que parecer é um verbo inacusativo, que se deixa descrever, portanto, pela estrutura (9):

(17) *A pedra parece feliz

Como se explica agora a anomalia semântica de (17)? A explicação segue a linha do que foi dito para chover em (16b) e pode ser estendido a todos os exemplos com parecer. A anomalia não se localiza na relação de $a$ pedra com parecer (mesmo porque esta relação já não apresentou anomalia em (14b)), mas na relação entre a pedra e o adjetivo feliz: a pedra é um DP semanticamente incompatível com feliz, de quem é efetivamente o argumento.

Assim, o que mostramos foi que existem verbos inacusativos, que se caracterizam por terem a estrutura argumental apresentada em (9); o detalhe a ser realçado é que eles não têm AE. Para entendermos por que a tradição gramatical não admite em princípio uma estrutura como (9), temos que levar em conta que as línguas (pelo menos as nominativas) têm uma compulsão, nesta teoria traduzida por um princípio chamado Princípio da Projeção Estendida (EPP): toda sentença tem sujeito. ${ }^{9}$ Assim, mes-

9 As línguas reagem de forma diferente à pressão do EPP. Algumas, que não toleram sujeito nulo, se caracterizam por preencher sistematicamente o Spec de IP, no limite por um (pronome) expletivo, como em (i). Outras, que toleram sujeito nulo, têm o Spec de IP preenchido por um expletivo nulo, como em (ii).

(i) a. It seems that John left expl parece-3Sg que John saiu 'Parece que John saiu' 
mo um verbo que não tem $\mathrm{AE}$, se ele é o verbo finito da sentença, pode acabar tendo um DP como sujeito. Este DP pode ser o XP de (9), se XP=DP, ou pode se originar dentro deste XP. O fato de eles poderem ter um DP como sujeito na aparência os iguala aos verbos que têm AE. Esta igualdade aparente induz de forma contra-intuitiva a considerar como sujeito mesmo um CP finito como em (10a) (oração subjetiva). Outro fator que torna a situação ainda mais complicada é o fato de que certos verbos inacusativos, como o próprio parecer, podem figurar em várias estruturas: às vezes está combinado com uma sentença apenas, que em situações normais aparece do lado direito do verbo (10a), às vezes está combinado com um sujeito à esquerda e algo do lado direito, como uma sentença infinitiva (12a) ou um predicativo (18):

(18) a. A Maria parece triste

b. A Maria parece uma freira

c. A Maria parece de ferro

Porém, se consideramos que a estrutura argumental de um verbo inacusativo é sempre como (9) (e deixamos para outros módulos da gramática a tarefa de explicar a estruturação final das sentenças), conseguimos fornecer uma análise unificada para toda a variedade de estruturas em que estes verbos podem figurar. Esta variedade de estruturas não é determinada em princípio pelo verbo em si, mas pelo tipo de complemento que o XP é: se for uma sentença infinitiva que contém um DP sem caso, este precisa ser movido para o Spec de IP para ter nominativo (19a); se for uma small clause (SC) com um DP sem caso, este precisa ser movido para Spec de IP para ter nominativo (19b); se for uma sentença finita (19c), nada precisa acontecer porque não vai existir DP sem caso.

(19) a. $\mathrm{L}_{\mathrm{IP}} \mathrm{A}$ Maria ${ }_{\mathrm{i}}$ parece $\mathrm{L}_{\mathrm{IP}} t_{\mathrm{i}}$ ter muitos amigos]

b. $\left[_{\mathrm{IP}}\right.$ A Maria ${ }_{\mathrm{i}}$ parece $\left[_{\mathrm{SC}} t_{\mathrm{i}}\right.$ triste $\left.]\right]$

c. $\complement_{\mathrm{IP}}$ Parece $\left[_{\mathrm{CP}}\right.$ que $\left[_{\mathrm{IP}}\right.$ a Maria tem muitos amigos $\left.\left.]\right\}\right]$

b. Il semble/parait que Jean est parti expl parece-3Sg que Jean é partido

'Parece que Jean partiu'

(ii) a. Expl parece que João foi embora

b. Expl sembra che Gianni è partito parece-3Sg que Gianni épartido 'Parece que Gianni partiu' 
Admitir a existência de verbos inacusativos produz uma reviravolta considerável na classificação tradicional dos verbos. Seus efeitos podem ser observados em (20):

Nova classificação

\section{Verbos lexicais}
a. verbos transitivos

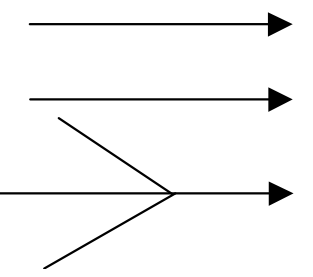
1. verbos transitivos
b. verbos intransitivos
2. verbos inergativos
c. verbos de ligação
d. verbos auxiliares
3. verbos inacusativos

O que se observa em (20), em primeiro lugar, é que a classe dos verbos transitivos se mantém inalterada, sua estrutura argumental sendo (7c) e (7d). A classe dos intransitivos perde uma boa parte de seus membros para a classe dos inacusativos. ${ }^{10} \mathrm{~A}$ classe dos verbos de ligação apresenta propriedades de inacusativos que, como representado em (19b), têm como complemento uma SC. A classe dos auxiliares apresenta propriedades de verbos inacusativos que selecionam como complemento um constituinte verbal como um InfP, um GerP ou um PartP.

Admitir a existência da classe dos inacusativos é especialmente importante à medida que permite reconsiderar o que era uma classe unitária, a dos verbos intransitivos, como sendo agora duas classes de verbos monorgumentais: uma, cuja estrutura é como (7b), a dos inergativos, que têm sempre um AE que é um DP; e outra, cuja estrutura é como (9), a dos inacusativos, que tem um AI de categoria variada. $\mathrm{O}$ que é de particular interesse para este nosso estudo é a situação em que o AI de um verbo inacusativo é da categoria DP, o que o torna em quase tudo igual a um verbo inergativo.

\footnotetext{
10 Existem verbos que participam de duas classes, alternando de dois para um argumento. Como nota um parecerista anônimo, a classificação tradicional também neste caso teria que postular que estes verbos participam de mais de uma classe verbal. Trataremos deles mais adiante.
} 


\subsection{Inergativos versus inacusativos}

Chegamos à conclusão de que, quando um verbo seleciona apenas um DP, sua estrutura argumental é como (21a) ou (21b):

(21) a.

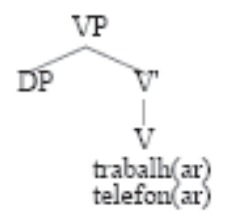

b.

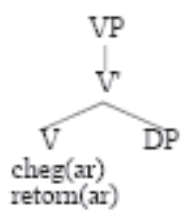

Nas sentenças com cada um destes verbos, no entanto, a diferença pode ser anulada porque o DP pode aparecer antes do verbo finito em ambas as situações, como vemos em (22): ${ }^{11}$

(22) a. A Maria tinha trabalhado no final de semana anterior

b. A Maria tinha chegado no final de semana anterior

Assim, para o português parece de todo ocioso traçar e manter a distinção em (21). A distinção parece ociosa também quando temos em vista o uso do auxiliar, já que no português não há variação: o auxiliar é sempre ter.

Entretanto, afirmamos que, mesmo para o português a distinção apresentada em (21) não é ociosa. Vamos nos limitar a apresentar um só fenômeno que justifica que se faça a distinção entre esses tipos de verbos monoargumentais. Observemos construções de particípio absoluto, como as de (23):

(23) a. Acabado o trabalho, todos tiraram férias

b. Chegada a hora, todos foram embora

c. *Telefonada a Maria, João saiu

A sentença (23c), construída com telefonar, é agramatical, enquanto (23b), construída com chegar, é gramatical. Se mantemos a distinção apre-

11 Porém, há situações em que é mais difícil que o DP apareça antes do verbo finito. Tome como exemplo uma sentença cujo verbo é existencial:

(i) a. Existe uma gota de sangue em cada poema

b. *Uma gota de sangue existe em cada poema 
sentada em (21), conseguimos dar uma explicação para o que acontece em (23). Observe primeiramente que a construção de particípio absoluto é bem formada com um verbo transitivo, como acabar em (23a), e que o DP o trabalbo, com o qual o particípio concorda, corresponde ao seu AI. O que acontece quando se trata de verbos monoargumentais? O que acontece é que, se o argumento é o AI, como dissemos ser o caso para chegar, a sentença é gramatical (23b), com o particípio concordando com ele; se, por outro lado, o único argumento corresponde ao $\mathrm{AE}$, como dissemos ser o caso para trabalhar ou telefonar, a sentença é agramatical (23c). Assim, só verbos como acabar ou chegar, que têm AI, podem figurar numa construção de particípio absoluto. Se os verbos monoargumentais constituíssem uma classe homogênea, como quer a gramática tradicional, esperaríamos que a construção com particípio fosse completamente impossível para eles. Em outras palavras, a possibilidade de (23b) contra a impossibilidade de (23c) é regulada pelo fato de o único argumento de chegar ser um AI e o de telefonar ser um AE.

Esperando ter mostrado que a classificação dos verbos monoargumentais em inergativos e inacusativos é relevante, mesmo numa língua como o português, vamos agora buscar parâmetros para reconhecer se um verbo monoargumental é inacusativo ou inergativo. Se é possível apontar uma propriedade formal que define um verbo inacusativo, ${ }^{12}$ ficará em muito facilitada a tarefa de mostrar com quais verbos se usam os auxiliares essere e avere em italiano, ou être e avoir em francês; e com quais se pode usar o pronome clítico ne do italiano ou en do francês.

Nossa questão é, então, a seguinte: como reconhecer se um verbo monoargumental é inergativo (21a) ou inacusativo (21b)? Podemos simplificar o problema se reformulamos a pergunta da seguinte maneira: como reconhecer se o DP que é o único argumento de um verbo é o AE ou o AI?

Relembremos o que foi dito sobre a relação entre o verbo e seu AE: o verbo sempre impõe pesadas restrições sobre aquilo que é seu AE. Primei-

\footnotetext{
12 Em princípio, identificar o conjunto de verbos pelo tipo de interpretação que tem o verbo, como fazem as gramáticas de italiano e de francês, tende a ser mais complicado porque um verbo como affondare (afundar) em italiano ora pode ser empregado com um ora com outro auxiliar sem que suas propriedades semânticas se alterem. Em francês, os casos são mais matizados De qualquer forma, para formular a distinção pertinente em termos semânticos seria necessário lançar mão de uma teoria semântica muito mais sofisticada do que a utilizada pelas gramáticas tradicionais.
} 
ro, o AE tem que ser um DP. Acrescentemos que o $\mathrm{AE}$ tem que ter um papel temático proeminente, o que significa para os propósitos deste trabalho ser o agente. ${ }^{13}$ Quanto ao AI, ele não precisa ser um DP, como mostramos a propósito de (8). Além disso, a posição que o AI ocupa é prototípica do papel temático tema (paciente, afetado), o menos proeminente na estrutura temática de um verbo.

Agora estamos em condições de reconhecer se o DP que é o único argumento do verbo é o AI ou o AE, ou seja, se o verbo em questão é inacusativo ou inergativo. Um verbo é inergativo se o único argumento que ele seleciona tem que ser o agente. Um verbo é inacusativo se o único DP que ele seleciona não tem que ser agente. Apliquemos esta definição ao conjunto de sentenças em (24):

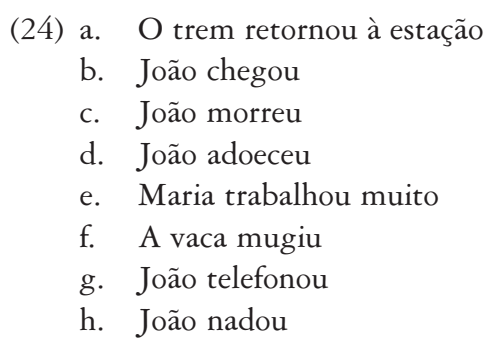

Agora somos levados a concluir que os verbos das sentenças (24a-d) são inacusativos, enquanto os das sentenças (24e-f) são inergativos. Note que em (24a) o argumento é inanimado, o que imediatamente coloca retornar, tal como ele ocorre nesta sentença, na classe dos inacusativos; em (24b), o DP animado João pode alternar com um inanimado como a encomenda, por exemplo, o que mostra que o verbo chegar não tem que selecionar agente; e em (24c-d), embora o DP sujeito tenha que ser animado (ou pelo menos vivo), ele tem o papel temático de tema, com a propriedade semântica de ser o afetado - isto é, João não é agente de sua morte, mas o seu paciente. Por sua vez, todos os verbos que ocorrem nas sentenças (24ef) exigem que seu sujeito seja agente e, por isso, devem se classificados como inergativos.

13 Outros papéis temáticos proeminentes são o de causador e o de experienciador. 
Vamos ver como esta distinção traçada para o português ajuda os professores a ensinar os aprendizes de italiano e francês a reconhecer os verbos com os quais se usa o auxiliar essere ou être e o pronome ne ou en e o auxiliar avere ou avoir.

\section{O Italiano e o Francês}

\subsection{Os pronomes cliticos partitivos ${ }^{14}$}

\subsubsection{O Italiano}

Uma das particularidades da gramática do italiano é um de seus pronomes clíticos, o ne. Dentre os vários usos que este pronome tem, destacamos um, o chamado "ne partitivo", que pode ser descrito grosso modo como se segue: é possível pronominalizar parte de um DP, desde que a parte que reste seja um elemento de tipo quantificacional, como molti, tanti, due ou ter (cf. Burzio, 1996). Que só DPs podem ser pronominalizados deste modo por ne é mostrado pelo contraste abaixo em (25):

(25) a. Gianni inviterà [molte ragazze]

Gianni convidará muitas meninas

'Gianni convidará muitas meninas'

b. (Di ragazze) Gianni ne inviterà [molte - ]

de meninas Gianni delas convidará muitas

Gianni convidará muitas meninas'

c. Gianni ha parlato [a [molte ragazze]]

Gianni tem falado a muitas meninas

'Gianni falou a muitas meninas'

d. *(Di ragazze) Gianni ne ha parlato [a [molte - ] ]

de meninas Gianni deles tem falado a muitos

Quando fazemos cliticização de ne a partir do DP molte ragazze em (25a) - um objeto direto nos termos da gramática tradicional, o resultado é (25b), que é uma sentença perfeita; contudo, se tentamos fazer o mesmo a partir do sintagma preposicional (PP) a molte ragazze em (25c) - um

\footnotetext{
14 Chamamos a estes pronomes de clíticos porque eles, como os outros oblíquos átonos, devem aparecer ao lado do verbo flexionado da sentença, sendo-lhes impossível permanecer no lugar ocupado pelos DPs plenos.
} 
objeto indireto na gramática tradicional, o resultado é a sentença (25d), que é agramatical.

Mas nem todos DPs com este formato podem ser pronominalizados por $n e$. Considere as sentenças em (26), onde é o AE do verbo que tem o formato quantificacional:

(26) a. [Tante ragazze] hanno invitato Gianni muitas meninas têm convidado Gianni

'Muitas meninas convidaram Gianni'

b. * (Di ragazze) [Tante - $]$ ne hanno invitato Gianni de meninas muitas delas têm convidado Gianni

c. * (Di ragazze) $\mathrm{Ne}$ hanno invitato Gianni [tante -] de meninas delas têm convidado Gianni muitas

O que (26b) mostra é que é impossível a cliticização de ne a partir do AE; ela continua sendo impossível mesmo que ele esteja ocupando a posição pós-verbal, como em (26c), uma posição bastante usual para os sujeitos em italiano. A generalização que emerge destes dados é que a cliticização de ne só é possível se é feita a partir de DPs que são AIs.

O leitor atento já imagina onde queremos chegar: se a cliticização do ne partitivo é um diagnóstico para AIs, e se a hipótese inacusativa afirma que existem verbos monoargumentais que só possuem $\mathrm{AI}$, a previsão é que os verbos inacusativos admitirão a cliticização de $n e$, ao passo que os verbos inergativos serão resistentes a esse processo. Dito de outro modo, contra a gramática tradicional - que, por admitir uma única classe de verbos monoargumentais, diria que eles devem se comportar uniformemente com respeito a cliticização do ne partitivo -, aqui esperamos dois comportamentos distintos para os verbos monoargumentais. Observe (27) e (28) abaixo:

(27) a. Tanti ragazzi sono arrivati muitos meninos são chegados 'Muitos meninos chegaram'

b. Sono arrivati tanti ragazzi são chegados muitos meninos 'Chegaram muitas meninas'

c. Ne sono arrivati tanti deles são chegados muitos 'Muitos deles chegaram' 
(28) a. Tanti ragazzi hanno lavorato muitos meninos têm trabalhado 'Muitos meninos trabalharam'

b. Hanno lavorato tanti ragazzi têm trabalhado muitos meninos

c. * Ne hanno lavorato tanti deles têm trabalhado muitos

(27) ilustra o comportamento de um verbo inacusativo, como arrivare (chegar), que não seleciona um sujeito necessariamente agente. (27a) é uma sentença com sujeito pré-verbal e (27b) uma sentença com sujeito pós-verbal. Ambas são perfeitas em italiano. Também é perfeita a cliticização do ne, o que implica que estamos lidando com um AI, dado o que acabamos de ver sobre as possibilidades de cliticização de ne. Por outro lado, (28) ilustra o comportamento de um verbo inergativo, como lavorare, que seleciona um sujeito necessariamente agente. Aqui também tanto o sujeito pré-verbal, em (28a), quanto o sujeito pós-verbal, em (28b), são possíveis, mas a cliticização de ne fornece o resultado agramatical que vemos em (28c). Esta situação é o que esperamos se de fato estamos às voltas com um AE. O contraste entre (27c) e (28c) demole a idéia de que a classe de verbos monoargumentais é homogênea.

\subsubsection{O Francês}

O francês também dispõe de um pronome clítico que, dentre os seus vários usos, apresenta um que pode ser chamado "en partitivo". A descrição de sua distribuição é fundamentalmente idêntica a de ne: en pronominaliza parte de um DP, desde que a parte restante seja um elemento de tipo quantificacional, como beaucoup, plusieurs, deux ou trois. Também em francês dá-se que só DPs podem ser pronominalizados deste modo por en, como mostra (29) abaixo:

(29) a. Jean invitera [plusieurs filles]

Jean convidará várias meninas

'Jean convidará várias meninas'

b. (De filles) Jean en invitera [plusieurs -]

de meninas Jean delas convidará muitas

'Jean convidará muitas meninas' 
c. Jean parlera [a [plusieurs filles]]

Jean falará a várias meninas

'Jean falará a várias meninas'

d. *(De filles) Jean en parlera [a [plusieurs - ]]

de meninas Jean delas falará a muitas

(29) mostra os mesmos fatos que (25): a cliticização de en a partir do DP plusieurs filles em (29a) dá como resultado uma sentença perfeita, (29b); por outro lado, se tentamos fazer o mesmo a partir do PP a plusieurs filles em (29c), o resultado é uma sentença agramatical, como vemos em (29d).

E como no italiano, também em francês nem todos DPs com este formato podem ser pronominalizados por en, o que se pode ver nas sentenças em (30), onde é o AE do verbo que tem o formato quantificacional:

(30) a. [Plusieurs filles] inviteront Jean várias meninas convidarão Jean

'Várias meninas convidarão Jean'

b. *(De filles) [Plusieurs - ] en inviteront Jean de meninas muitas delas convidarão Jean

(30b) mostra que é impossível a cliticização de en a partir do AE. O leitor atento observará que não estamos reproduzindo em francês o exemplo (26c) do italiano, que exibe o sujeito em posição pós-verbal, uma situação muito comum em italiano mesmo com verbos transitivos. Na verdade, por razões independentes, o francês não aceita livremente construções com sujeito pós-verbal como o italiano; no entanto, em algumas circunstâncias isso é possível, como exemplificado por (31a); no entanto, como no italiano, a posição pós-verbal do AE não garante gramaticalidade na cliticização de en. Assim, a mesma generalização emerge aqui também: a cliticização de en só é possível se é feita a partir de DPs que são AIs.

(31) a. Le moment où l'ont vu [plusieurs filles] était chaotique o momento onde o têm visto várias meninas era caótico 'O momento em que várias meninas o viram era caótico'

b. *Le moment où en l'ont vu [plusieurs - était chaotique o momento onde delas o têm visto várias era caótico

E se a generalização é a mesma, a previsão que fazemos para o caso do francês é também a mesma: os verbos inacusativos do francês admitirão a 
cliticização de en, ao passo que os verbos inergativos serão resistentes a esse processo. É possível mostrar que a predição se confirma, mas talvez seja necessário dizer ainda algumas palavras sobre a existência de sujeito pósverbal em francês. Sem entrar em muitos detalhes, podemos dizer que (31a) é um dos poucos contextos em que se vê o sujeito após o verbo e a posição pré-verbal de sujeito vazia. A posição de sujeito pré-verbal não pode permanecer vazia numa língua que não é de sujeito nulo como é o caso do francês. A saída do francês para situações em que o sujeito aparece em posição pós-verbal é preencher a posição de sujeito pré-verbal com um pronome expletivo como il, por exemplo. Agora podemos voltar à predição: novamente, ainda que a construção com sujeito pós-verbal relacionado a um pronome expletivo na posição pré-verbal seja fundamentalmente possível com qualquer verbo monoargumental, só as construções com verbos inacusativos aceitam a cliticização de $e n$, como vemos em (32) e (33) abaixo:

(32) a. Plusieurs filles sont arriveés várias meninas são chegadas 'Várias meninas chegaram'

b. Il est arrivé plusieurs filles expl é chagada muitas meninas

'Muitas meninas chegaram'

c. (De filles) Il en est arrivé plusieurs de meninas expl delas é chegadas muitas

'Muitas meninas chegaram'

(33) a. Plusieurs filles ont travaillé várias meninas têm trabalhado 'Várias meninas trabalharam'

b. * Il a travaillé plusieurs filles expl tem trabalhado muitas meninas

c. * Il en a travaillé plusieurs expl delas tem trabalhado muitas

(32) ilustra o comportamento de um verbo inacusativo, como arriver, que não seleciona um sujeito necessariamente agente. (32a) é uma sentença com sujeito pré-verbal e ( $32 \mathrm{~b}$ ) uma sentença com sujeito pós-verbal associado ao il expletivo pré-verbal. Ambas são perfeitas em francês. Também é perfeita a cliticização do en, o que implica que plusieurs filles é um AI, dada a discussão anterior sobre as possibilidades de cliticização de en. Por 
outro lado, (33) ilustra o comportamento de um verbo inergativo, como travailler, que seleciona um sujeito necessariamente agente; (33a) ilustra o caso de sujeito pré-verbal e (33b), a construção com sujeito pós-verbal associado a um expletivo pré-verbal. No entanto, como nossa hipótese prevê, é impossível a cliticização de en num caso como este, o que vemos em (33c). Assim, apesar de observarmos diferenças entre o francês e o italiano no que diz respeito à sintaxe do sujeito nulo, no que concerne às possibilidades de cliticização do partitivo essas duas línguas partilham a mesma propriedade, que é a de permitir esse processo apenas a partir de seus AIs. Por isso, esta propriedade é um diagnóstico para a inacusatividade: dentre os verbos monoargumentais, apenas verbos inacusativos permitem a cliticização do partitivo.

\subsection{A seleção de auxiliares}

\subsubsection{Italiano: Essere versus Avere}

A gramática tradicional e os métodos de ensino de língua têm uma dificuldade considerável para explicitar com quais verbos monoargumentais se usa o auxiliar essere (ser) e com quais o avere (ter) para a formação do passato composto do italiano. Em particular, o problema é definir um critério para sustentar a escolha: a opção é quase sempre por uma abordagem semântica segundo a qual os verbos monoargumentais que indicam movimento ou mudança de estado são os que selecionam essere, enquanto os outros selecionam avere.

Note, entretanto, que não é muito claro por que as coisas deveriam ser assim e não o seu exato oposto; em particular, não é clara qual pode ser a relação entre o auxiliar essere e a interpretação de movimento ou mudança de estado. Mas este não é o problema mais sério dessa abordagem; mais séria é sua inadequação empírica e sua incapacidade de levar os aprendizes a antever com quais verbos se usa um ou outro auxiliar. Vejamos um exemplo: sabemos que arrivare (chegar) é um verbo de movimento; portanto, deveria ter essere como auxiliar. Porém, esta conclusão não se sustenta se consideramos o verbo correre (correr) que indica movimento, mas é usado com o auxiliar avere, isto é, se diz (34a) em vez de (34b): 
(34) a. Maria ha corso (per due ore) Maria tem corrido por duas horas 'Maria correu por duas horas'

b. Maria è corsa (*per due ore) Maria é corrida por duas horas 'Maria correu (*por duas horas)'

Não vamos nos estender na discussão, porque parece claro que o critério semântico baseado na interpretação do verbo deixa muito a desejar para este fim. Vamos tentar estabelecer um critério sintático para uma escolha sintática: escolhe-se o auxiliar essere para fazer o passado composto de um verbo monoargumental se este é um verbo inacusativo, ou seja, se seu único argumento é um AI; por outro lado, a escolha recai sobre avere quando o verbo monoargumental em questão for um verbo inergativo, ou seja, se seu argumento é o AE. É exatamente este o padrão das sentenças em (27) e (28) acima.

Mas por que as coisas seriam desse jeito e não exatamente ao contrário? Uma resposta para esta pergunta se encontrará nas próximas subseções. Antes, porém, vamos examinar o caso do francês.

\subsubsection{Francês: Être versus Avoir}

Também quando está em discussão a gramática tradicional e os métodos de ensino de francês, nota-se a mesma dificuldade para explicitar com quais verbos monoargumentais se usa o auxiliar être (ser) e com quais se usa avoir (ter) para a formação do passé composé e de outros tempos compostos. O problema é sempre o de definir um critério razoavelmente explícito e consistente para a escolha de um ou outro auxiliar e a opção é quase sempre por uma abordagem semântica segundo a qual os verbos monoargumentais que indicam movimento, mudança de estado (ou ainda estabilidade, como demeurer ou rester!) são os que selecionam être, enquanto os outros selecionam avoir.

À parte a questão da consistência semântica destas noções - como as noções de "movimento", "mudança de estado" e "estabilidade" podem formar um todo coerente? "Estabilidade" não se configura como o oposto de "mudança"? - nunca fica claro por que as coisas deveriam ser assim e não 
de outro modo; também aqui não é clara qual pode ser a relação entre o auxiliar être e as mais diversas interpretações que o verbo lexical pode ter. Novamente a questão mais séria é a inadequação empírica desta abordagem também para o caso do francês. Se desenvolvermos aqui, para os verbos arriver, grandir, mourir e courir, o mesmo raciocínio desenvolvido para os verbos correspondentes do italiano, vamos chegar à mesma conclusão. Vamos usar apenas um exemplo a mais para dar a dimensão da inadequação da abordagem semântica:

(35) a. Elle a sorti ses vêtements de son armoire ela tem saido suas roupas de seu armário

'Ela tirou as roupas dela do armário dela'

b. Elle est sortie avec ses amis ela é saída com seus amigos 'Ela saiu com os amigos dela'

Em (35), apesar da diferença de significado do verbo sortir, fica preservado o sentido de movimento; entretanto, estas sentenças põem, para o tratamento semântico da questão, um problema muito difícil de ser contornado.

Por causa destes problemas investimos também aqui no estabelecimento de um critério sintático para uma escolha que é afinal sintática: escolhe-se o auxiliar être para fazer tempos compostos de um verbo monoargumental se este é inacusativo, ou seja, se seu argumento é um AI; por outro lado, a escolha é por avoir quando o verbo monoargumental em questão for inergativo, ou seja, se seu argumento é o AE. É exatamente este o padrão das sentenças em (32) e (33) acima.

Vamos agora tentar responder à questão: por que as coisas seriam desse jeito e não exatamente ao contrário?

\subsection{Passivas}

\subsubsection{Do Italiano}

As construções passivas são construções especiais nas línguas naturais porque elas de alguma forma "invertem" as construções ativas correspondentes: aquilo que era o objeto direto da sentença ativa se torna o sujeito 
da construção passiva, como vemos no exemplo do português em (36) e do italiano em (37):

(36) a. O inimigo afunda o navio

b. O navio é afundado (pelo inimigo)

c. $\mathrm{O}$ inimigo afundou o navio

d. O navio foi afundado (pelo inimigo)

(37) a. Il nemico affonda la nave

o inimigo afunda o navio

'O inimigo afunda o navio'

b. La nave è affondata (dal nemico)

o navio é afundado pelo inimigo

'O navio é afundado pelo inimigo'

c. Il nemico ha affondato la nave

o inimigo tem fundado o navio

'O inimigo afundou o navio'

d. La nave è stata affondata (dal nemico)

o navio é estado afundado pelo inimigo

'O navio foi afundado pelo inimigo'

Observemos primeiramente que a relação semântica que o sintagma 0 navio/la nave mantém com o verbo é exatamente a mesma nas duas orações: trata-se do tema. Em segundo lugar, é de se notar o fato de que o auxiliar da passiva é sempre ser/essere, seja em português, seja em italiano. Ora, mais uma vez é o auxiliar ser/essere que é o escolhido quando temos um AI tornando-se o sujeito da sentença.

Podemos levar às últimas conseqüências o que dissemos anteriormente e dizer que a construção passiva é uma construção inacusativa: toma o AI do verbo (que vemos ocupando a posição de complemento na sentença ativa) e o transforma em sujeito da sentença passiva.

A generalização então, proposta por Burzio (1986), é que o auxiliar essere só é escolhido quando estamos às voltas com a inacusatividade, ou seja, quando é o AI do verbo que ocupa a posição de sujeito. Em algumas línguas, como o italiano, todas as vezes que acontece isso, o auxiliar essere é escolhido. Isto é, usa-se essere cada vez que o AI sai da sua posição de objeto, seja por conta de um processo sintático, como é a apassivação, ou por conta de uma escolha lexical, como é a escolha de um verbo inacusativo. Já numa língua como o português, apenas quando o processo é sintático, 
como a formação da passiva, é que o auxiliar ser é escolhido. Podemos pensar então que estamos frente aos dois pontos extremos da escala de representação da inacusatividade, e então é possível colocar a questão: será que existem línguas que mostram algum ponto intermediário desta escala, isto é, que escolhem o auxiliar ser para alguns casos de inacusatividade para além da passiva, mas não em todos os casos em que o AI passa a ser o sujeito da sentença? A resposta vem a seguir.

\subsubsection{Do Francês}

O francês também dispõe de construções passivas, com propriedades idênticas às observadas em português ou italiano, como mostra a comparação de (38) e (39):

(38) a. O submarino afunda vários navios

b. Vários navios são afundados (pelo submarino)

(39) a. Le sous-marin coule plusieurs navires o submarino afunda vários navios 'O submarino afunda vários navios'

b. Plusieurs navires sont coulés (par le sous-marin) vários navios são afundados por o submarino 'Vários navios são afundados pelo submarino'

Novamente, a relação semântica que o sintagma vários navios/plusieurs navires mantém com o verbo é a mesma nas orações (38a) e (38b): trata-se do tema. Nota-se igualmente o fato de que o auxiliar da passiva é être em francês e, portanto, mais uma vez é o auxiliar être que é o escolhido quando temos um AI tornando-se o sujeito da sentença, o que é esperado se a construção passiva está no rol das construções inacusativas. Podemos afirmar, portanto, que a generalização proposta por Burzio (1986) se sustenta também em francês: o auxiliar être só é escolhido quando estamos às voltas com a inacusatividade, ou seja, quando é o AI do verbo que ocupa a posição de sujeito. A pergunta é: em todas as situações de inacusatividade o francês escolhe o auxiliar être?

Vimos na discussão sobre o italiano que em todas as circunstâncias em que é o AI (ou parte dele) que se torna o sujeito da sentença o auxiliar essere é escolhido, independentemente de a sentença resultar de um processo 
sintático ou de uma escolha lexical. Já numa língua como o português, apenas quando o processo é sintático (como a formação da passiva) é que o auxiliar ser é escolhido - a escolha lexical do conjunto de verbos inacusativos é sempre por ter. Se estes são os dois pontos extremos da escala, não é difícil imaginar uma situação intermediária também: pode dar-se o caso de que exista uma língua que exija o auxiliar correspondente a ser em certas situações sintaticamente marcadas como inacusativas, mas que aceite o auxiliar correspondente a ter em outras; e o mesmo pode acontecer com as situações de escolha lexical: pode acontecer que com um subconjunto de verbos inacusativos a língua escolha ser, mas que com outro subconjunto admita ter. O que não se espera é que as línguas escolham ser ou ter aleatoriamente ou que escolham ser em situações que não se aparentam com a inacusatividade.

O francês é exatamente o exemplo de caso intermediário que estamos supondo existir. Nesta língua, certas escolhas lexicais e certas construções sintáticas que são casos de inacusatividade (pelos critérios examinados aqui) são marcadas para o uso do verbo avoir, casos em que esperaríamos ver être. Vamos primeiramente chamar a atenção do leitor para o fato de que a existência destes casos não é a priori um contra-argumento cabal para a hipótese da inacusatividade que estamos explorando. Também não invalida o objetivo deste estudo, que é o uso desta hipótese para tornar claro para os professores de francês e de italiano que auxiliar usar em que circunstâncias. No entanto, é necessário conseguir identificar precisamente em que contextos sintáticos a escolha é distinta da prevista pela versão mais forte da generalização.

O caso de escolha lexical mais importante é o caso do auxiliar usado nos tempos compostos do próprio verbo être, esteja ele sendo utilizado como auxiliar ou verbo de ligação, para utilizar os termos da gramática tradicional. Se os auxiliares e os verbos de ligação são verbos inacusativos (cf. diagrama em (20)) porque c-selecionam apenas o seu complemento, como vimos na discussão dos exemplos em (6) para os auxiliares e em (18)/(19) para os verbos de ligação, o que esperaríamos é que être utilizasse être para seus tempos compostos; no entanto, o que se observa é o uso de avoir nestas situações:

(40) a. Marie est belle Marie é bonita

'Marie é bonita' 
b. Marie a été belle dans sa jeunesse Marie tem sido bonita em sua juventude 'Marie foi bonita na juventude'

c. Les navires sont visités chaque jour os navios são visitados todo dia 'Os navios são visitados todo dia'

d. Les navires ont été visités chaque jour os navios são sido visitados todo dia

'Os navios foram visitados todos os dias'

Compare a sentença em (40d) com a sentença italiana em (37d) que mostra que o passado composto do auxiliar essere se faz também com o verbo essere: è stato - o problema do italiano aqui é outro: o particípio do verbo essere é o mesmo do verbo stare, uma situação que conhecemos em português com o particípio irregular dos verbos matar e morrer.

Veremos nas próximas subseções também um caso em que o francês faz uma escolha distinta da do italiano (e idêntica à do português) com respeito a uma alternância sintática que tem por efeito "inacusativizar" o verbo. Comecemos por examinar como o italiano trata tais construções em sua gramática.

\subsection{Construcõos 'Incoativas'}

\subsubsection{Em Italiano}

Um outro tipo de construção também estudada por Burzio (1986) como integrante do rol das construções inacusativas é aquele formado por verbos que permitem o seguinte par de sentenças:

(41) a. O inimigo afundou o navio

b. O navio afundou

Se o raciocínio que fizemos para a passiva na seção anterior está correto, podemos afirmar que em ( $41 \mathrm{~b})$ temos o AI do verbo tornando-se sujeito da sentença. A predição que a hipótese inacusativa faz para a seleção de auxiliares em italiano é clara: a tradução de (41a) deve escolher o auxiliar avere, pois se trata de uma construção transitiva; a tradução de (41b), por 
outro lado, deve escolher essere, já que aqui temos em mãos uma construção inacusativa. E é exatamente este o padrão encontrado em italiano: ${ }^{15}$

(42) a. Il nemico ha affondato la nave

o inimigo tem afundado o navio

'O inimigo afundou o navio'

b. La nave è affondata ${ }^{16}$

- navio é afundado

'O navio afundou'

Teremos ainda algo a dizer sobre a sentença em (42b) na próxima seção, quando examinaremos a tradução destas sentenças para o francês. Por agora, gostaríamos apenas de frisar que a idéia de inacusatividade, mesmo que pareça complicada à primeira vista, é bastante interessante porque explica uma série de fenômenos aparentemente não relacionados, $\mathrm{o}$ que, para o aprendiz brasileiro de italiano, representa uma economia considerável no esforço de resolver a questão da seleção de auxiliares.

\subsubsection{Em Francês}

Em francês, por seu turno, é possível observar um padrão de seleção de auxiliares idêntico ao do português (utilizaremos o pretérito mais que perfeito composto para explicitar o auxiliar que o português usa nestas circunstâncias):

(41) a. O submarino tinha afundado o navio

b. O navio tinha afundado

(44) a. Le sous-marin avait coulé le navire

o submarino tinha afundado o navio

'O submarino tinha afundado o navio'

b. Le navire avait coulé

o navio tinha afundado

'O navio tinha afundado'

\footnotetext{
15 Ver uma vez mais que a adoção de um critério semântico para definir a classe de verbos que são usados com essere ou avere não é um bom caminho. Não é muito fácil explicar uma possível mudança de significado no verbo affondare de (42a) para (42b). Por outro lado, as diferenças sintáticas são transparentes: só em (42b) temos um caso em que o AI é o sujeito.

16 Note-se a diferença entre a construção passiva em (37d) e a "incoativa" em (42b), marcada pela presença do particípio stata na primeira, apesar de a significação temporal de ambas ser o passato prossimo.
} 
Observe que este tipo de construção é bastante parecido com a passiva, no sentido de que a relação semântica que existe entre o verbo e o objeto da ativa em (44a) é fundamentalmente a mesma que existe entre o verbo e o sujeito da construção monoargumental em (44b). No entanto, ao contrário da construção passiva, exemplificada em (39b), o auxiliar utilizado pelo francês é avoir, uma situação inesperada se existissem apenas dois pontos na escala da representação da inacusatividade. Parece então que estamos frente a um outro caso de escolha marcada, desta feita um caso de escolha sintática, ligado à construção "incoativa", que transforma um certo conjunto de verbos transitivos em verbos inacusativos.

Antes de prosseguirmos, talvez valha a pena compararmos o italiano, o francês e o português, visto que o francês permite o uso do verbo être numa sentença como (44b), mas a interpretação então só poderá ser resultativa - isto é, a sentença só pode ser expressão do "estado resultante da ação", nos termos da gramática tradicional. Observe (45) abaixo - as sentenças em italiano e francês são versões das sentenças em português:

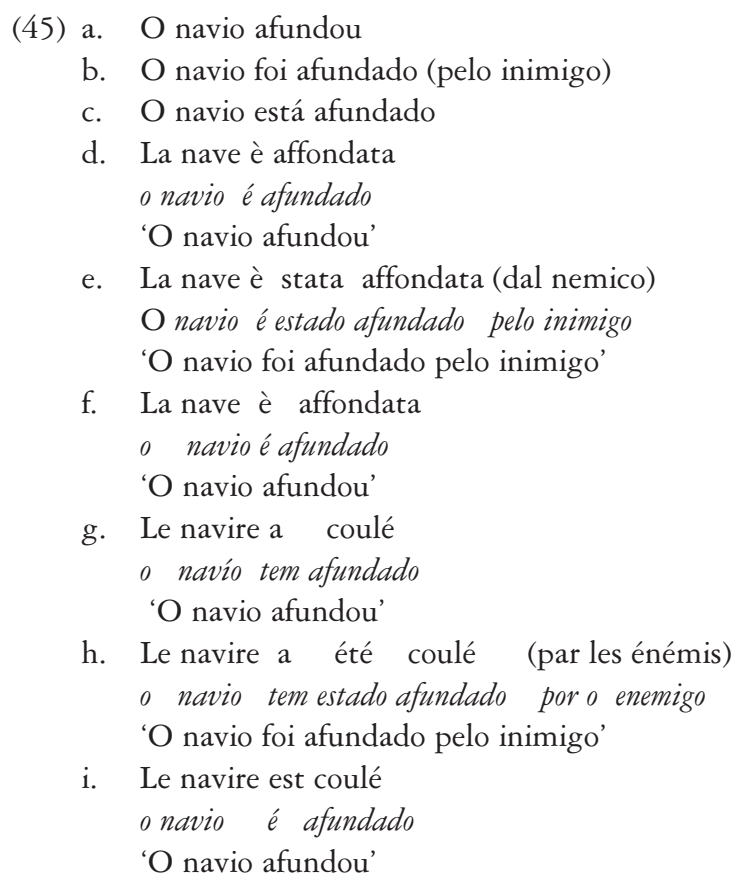

Não nos debruçaremos sobre estas diferenças entre as línguas em discussão, mas apenas chamamos a atenção do leitor para o ponto central de 
nossa discussão aqui: a afirmação que fazemos é que verbos ou construções com a propriedade da inacusatividade podem selecionar o auxiliar ser, mas não devem fazê-lo necessariamente (ou o português não poderia existir). Por outro lado, não esperamos que verbos ou construções não aparentadas com a inacusatividade possam selecionar o auxiliar ser para expressar tempos ativos. ${ }^{17}$

\subsection{Construções com o Clítico 'Se'}

\subsubsection{Do Italiano}

Um último tipo de construção examinado aqui é aquele que contêm o clítico si. Uma destas construções é exemplificada pelo par em (46):

17 No entanto, certos fatos ainda resistem a esta explicação tanto em francês quanto em italiano com respeito à seleção dos auxiliares. O mais interessante talvez seja o fato relacionado com o verbo scendere/descendre (descer), que exibe o seguinte padrão - note em particular o padrão transitivo das sentenças em (b):

(i) a. Il est descendu à la cave

ele está descido a o porão

'Ele desceu ao porão'

b. Il a descendu les escaliers quatre à quatre

ele tem descido as escadas quatro a quatro

'Ele desceu a escada de quatro em quatro'

(ii) a. Lui è sceso al mare

ele é descido ao mar

'Ele desceu para o mar'

b. Lui ha sceso le scale velocemente

ele tem descido a escada velozmente

'Ele desceu as escadas velozmente'

Os fatos são inesperados porque se observa a mudança do auxiliar sem que se alterem as relações sintáticas - aparentemente é sempre o mesmo elemento que aparece em posição sujeito. Mas talvez esta não seja a conclusão correta a tirar dos exemplos, dado o contraste interpretativo que podemos observar em português mesmo - e que seguramente se repete também em italiano e francês:

(iii) a. A pedra desceu para o fundo do lago

b. *A pedra desceu as escadas (rapidamente)

Não nos estenderemos nesta discussão aqui, notando apenas que estes casos, ainda que mais complexos, se amoldam à mesma generalização que os outros: os verbos inacusativos não necessitam de sujeitos agentes, sendo por isso compatíveis com sintagmas inanimados. Agradecemos a Izabel C. Seara por ter chamado a nossa atenção para estes fatos do francês. 
(46) a. Il vento ha sparso le nuvole o vento tem dissipado as nuvens 'O vento disssipou as nuvens'

b. Le nuvole si sono sparse as nuvens se são dissipadas 'As nuvens (se) dissiparam'

Em comparação com (42), a diferença que sobressai em (46) é a presença obrigatória do clítico $s i,{ }^{18}$ às vezes identificado como clítico incoativo. O que interessa é, de novo, a alternância do auxiliar: avere para a versão transitiva do verbo e essere para a versão inacusativa. Como nos casos anteriores, entendemos o uso de essere em (46b) quando observamos que o sujeito é o AI. (47b):

Outra construção é a que contém um clítico si reflexivo, como em

(47) a. Gianni ha ferito Maria
Gianni tem machucado Maria
'Gianni machucou Maria'
b. Maria si è ferita
Maria se é machucada
'A Maria se machucou'
c. Maria ha ferito sé stessa
Maria tem machucado si mesma
'A Maria machucou a si mesma'

Em (47a) e (47c) o auxiliar usado é avere enquanto em (47b) é essere. (47a) não requer comentários adicionais uma vez que repete a estrutura transitiva com o AI como objeto. O problema é explicar à luz da hipótese que estamos sustentando que exista a alternância de uso de auxiliar entre (47b) e (47c). Ou seja: se nestas duas sentenças a interpretação é reflexiva (o que significa mais que nunca que o verbo ferire significa a mesma coisa

18 Observar que a sentença (i) é gramatical no italiano, mas com uma interpretação diferente de (46b):

(i) Le nuvole sono sparse

as nuvens são dissipadas

'As nuvens (se) dissiparam'

A interpretação de (i) é semelhante à sentença resultativa do português As nuvens estão dissipadas. 
independentemente do auxiliar com que é usado), como se explica que em (47c) é o auxiliar avere que é usado e em (47b) é o auxiliar essere? Como manter, face a (47), a hipótese de que o auxiliar essere é sempre usado quando o AI se torna o sujeito?

Vamos responder a pergunta com base na idéia de Sportiche (2000) de que os reflexivos si e sé stessa têm estatuto diferente. O último tem estatuto de AI pleno, o que podemos deduzir de, pelo menos, uma de suas propriedades: não pode ser um clítico, pois ele ocorre depois do particípio ferita, posição que não é própria para um clítico. Se sé stessa é o AI, então o sujeito Maria em (47c) só pode ser o AE.

Por sua vez, por ser clítico, si não tem estatuto de AI pleno, como dissemos ser o caso para sé stessa. Claramente, a posição que ele ocupa junto ao auxiliar è não é a posição própria do AI. Como o agente e o paciente da ação de ferir coincidem, não temos como comprovar que Maria seja o $\mathrm{AE}$ em (47b). Por causa desta indefinição, conseguimos reconciliar o uso do auxiliar essere nas construções reflexivas com a hipótese que vimos sustentando: o auxiliar essere é usado em (47b) porque Maria é um AI que está funcionando como sujeito, como em todos os casos apontados anteriormente.

\subsubsection{Do Francês}

Também em francês é possível uma série de construções que contêm o clítico se. A construção correspondente a (46) do italiano é exemplificada em (48) abaixo:

(48) a. Le soleil a dissipé la brume

- sol tem dissipado a bruma

'O sol dissipou a bruma'

b. La brume s'est dissipée

a bruma se está dissipada

'A bruma se dissipou'

O francês exibe igualmente a alternância do auxiliar: avoir para a versão transitiva do verbo e être para a versão inacusativa, exatamente quando o sujeito da sentença é o AI do verbo, como esperado. 
A outra construção com o clítico se que vai nos interessar é construção reflexiva, que podemos examinar em (49b) abaixo:

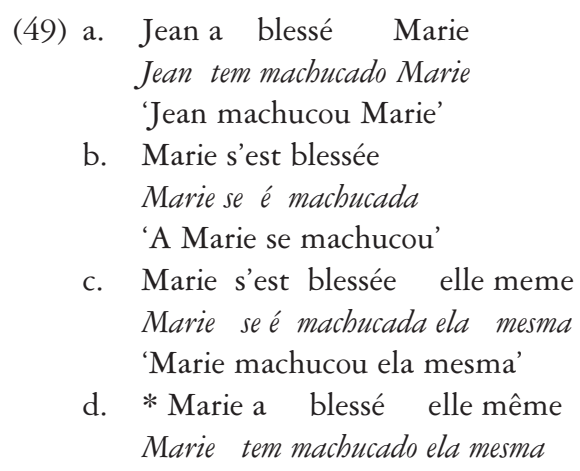

Como vemos em (49c,d), os fatos do francês são distintos dos do italiano no que se refere ao uso do reflexivo forte. Em primeiro lugar, a forma do reflexivo deve ser elle même (ou lui-même no caso de o sujeito ser do gênero masculino) e não soi-même, que pode ser utilizado somente em construções impessoais, como (50):

(50) Pour que les fraix médicaux soient remboursés, il faut ne pas se para que as despesas médicas sejam reembolsadas expl precisa não se blesser soi-même machucar si-mesmo

'Para que as despesas médicas sejam reembolsadas, é necessário não se machucar a si mesmo'

Em segundo lugar, é importante notar que o francês não admite o uso do reflexivo forte sozinho, como o italiano, mas sempre em co-ocorrência com o pronome clítico, ao que tudo indica numa construção de redobramento.

Como explicar estes fatos, dado o que dissemos para o caso do italiano? Aparentemente, o francês e o italiano representam os seus reflexivos fortes de maneira muito diferente, de modo que se em italiano podemos afirmar que o reflexivo forte sé stessa tem estatuto de AI pleno, em francês, ao contrário, deveríamos dizer que seu estatuto não é de $\mathrm{AI}$ pleno. $\mathrm{O}$ fato mesmo de a forma do reflexivo forte ser lui-même ou elle-même e jamais soimême (em contextos pessoais) é já bastante interessante, dado que estas são 
também as formas utilizadas em construções enfáticas ou contrastivas quando o que está sendo enfatizado ou contrastado é o sujeito da sentença:

(51) a. Jean est venu lui-même

Jean é vindo ele-mesmo

'João veio em pessoa'

b. Marie l'a fait elle-même

Marie o tem feito ela-mesma

'A Maria que fez (isso)'

Observemos adicionalmente que, mesmo estando indiscutivelmente relacionado com a posição de sujeito (que pode ser preenchida por um AI em (51a) ou um AE em (51b)), a posição que lui-même e elle-même ocupam na sentença é pós-verbal - pós-participial, na verdade. Por outro lado, o italiano não aceita jamais sé stessa em construções do mesmo tipo de (51):

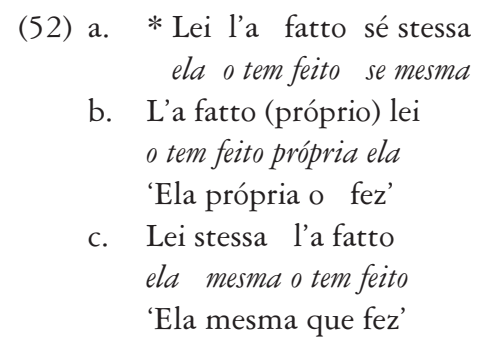

Portanto, parece possível afirmar que as formas elle-même ou lui-même estão sempre ligadas à posição de sujeito, formando com o elemento que ocupa esta posição uma estrutura de redobramento (o redobro então não é com o clítico, como é o caso de outras línguas com estruturas redobradas, como o espanhol). E se o que dissemos sobre o estatuto do reflexivo forte em francês está correto, parece clara a razão da presença obrigatória de se na construção: este é o único meio de identificar a construção como reflexiva. O que lui mêmelelle même está redobrando, podemos dizer, é o sujeito da sentença e a presença do auxiliar être ou avoir deve ser creditada a fatores independentes: em (51a) être se deve ao inacusativo arriver; em (51b) avoir se deve ao transitivo faire; e em (49c) ao clitico reflexivo se, que permite afirmar que Marie é o AI movido para a posição de sujeito. A propriedade destas observações deve ser ainda investigada com mais vagar, mas este primeiro quadro dos fatos nos permite reconciliar esses dados e o que afirma- 
mos ao longo deste texto: être é o auxiliar usado em (49b,c) porque Marie é aqui um AI que está funcionando como sujeito, como em todos os casos apontados anteriormente.

\section{Conclusão}

Este trabalho tentou fazer uma ponte entre a lingüística teórica e a lingüística aplicada tendo em vista o ensino de italiano e de francês para brasileiros. Para tanto, apresentamos a hipótese inacusativa, segundo a qual existem verbos que têm um único argumento que é interno. Por conta de uma série de fatores, este argumento acaba sendo o sujeito da sentença. $\mathrm{O}$ fato de o sujeito corresponder ao AI possibilita entender por que a classe de verbos identificados como inacusativos apresentam uma distribuição especial para o clítico ne ou en e por que escolhem o auxiliar essere ou être.

Evidentemente, as línguas podem diferir na extensão em que suas gramáticas explicitam a propriedade da inacusatividade. O português, por exemplo, não tem nenhum clítico partitivo nem exibe alternância de auxiliar em tempos ativos, mas nem por isso deixa de mostrar certas diferenças em determinadas construções que apontam para a existência também nesta língua de uma subclasse dos verbos mono-argumentais que põe em jogo um AI, não um AE. Por outro lado, o italiano apresenta uma situação que representa o outro lado da escala: todas as vezes que um AI passa a ocupar a posição sujeito da sentença o auxiliar escolhido é essere. Vimos aqui que o francês é um exemplo da situação intermediária: nem sempre que o AI se torna o sujeito da sentença o auxiliar utilizado é être, mas crucialmente é possível isolar com bastante precisão quais são as construções sintáticas ou os itens lexicais que fazem a escolha por avoir, de modo que o conhecimento da hipótese inacusativa pode ser útil também para orientar os professores de francês a escolher adequadamente o auxiliar que usarão nesta ou naquela construção.

Finalmente, gostaríamos de frisar que a hipótese inacusativa faz predições corretas em um número grande de casos aparentemente desconectados dentro da gramática - passivas, clítico en/ne, clítico se, escolha do auxiliar ser/ter, particípio absoluto - , um fato por si mesmo surpreendente sob o ponto de vista da gramática tradicional e muito interessante para 
aqueles que, além de ensinarem/aprenderem uma língua estrangeira, desejam compreender como funcionam os sistemas lingüísticos humanos. ${ }^{19}$

\author{
E-mails: \\ oto@cce.ufsc.br \\ llv1mcf@cce.ufsc.br
}

\title{
ReferênCias Bibliográficas
}

Burzio, L. 1986. Italian syntax. Amsterdam: Kluwer Academic Publishers. Grevisse, M. 1988. Le bon usage. Paris: Duculot.

Haegeman, L.1991. Manuale di grammatica generativa: la teoria della reggenza e del legamento. Milão: Ulrico Hoepli Editore S.p.A.

Koopman, H. \& Dominique S. 1991. The position of subjects. Lingua 85: 211-285.

Mioto, C., M. C. Figueredo Silva \& R. E. V. Lopes. 2004. Novo manual de sintaxe. Florianópolis: Insular.

Sportiche, D. 2000. Partitions and atoms of clause structure. New York: Routlegde.

\footnotetext{
19 Agradecemos a um parecerista anônimo que nos ajudou a tornar alguns pontos mais claros, discutindo-os. Vários comentários seus foram incorporados nesta versão. Não incorporamos, contudo, dois pontos. O primeiro é a sugestão de que se pode assentar a explicação simplesmente na agentividade do sujeito e fugir das complicações que o estudo da inacusatividade na sintaxe levanta para o aprendiz de italiano ou francês. A sugestão, no entanto, enfrenta a dificuldade de faltar um conceito bem demarcado da noção de agente na literatura. E, embora este procedimento simplificador resolva muitos casos, ele não enseja uma visão geral do fenômeno: ignorar a condição sintática de AI do sujeito inacusativo dificulta que certas relações sejam feitas e que se unifique o tratamento dos fenômenos envolvidos na inacusatividade. Considere o fenômeno dos clíticos partitivos. Como entenderíamos que eles se aplicam também ao objeto direto se não fosse mostrado que objeto direto e sujeito inacusativo têm em comum a propriedade de serem AI? Acrescente-se ainda o fato de que existem outros papéis semânticos nas sentenças das línguas, como Experienciador ou Instrumental, que não entram na generalização semântica que vê apenas Agentes e Pacientes (ou Temas), mas de qualquer modo estas sentenças escolhem auxiliares para seus tempos compostos. O segundo ponto é o alerta do parecerista sobre o perigo de o artigo ser circular: "sabemos que um verbo é inacusativo em italiano e francês se soubermos qual auxiliar selecionar e se o uso dos clíticos partitivos é possível. E saberemos qual auxiliar selecionar e se podemos usar os pronomes partitivos se soubermos que o verbo é inacusativo". Na verdade, a proporção que se depreende do texto, salvo desatenção de nossa parte é: sabemos que um verbo é inacusativo se ele tem apenas o AI; se ele tem apenas AI, que é um DP, este vai ser o sujeito da sentença; então, o sujeito (posposto) vai poder ser cindido pelo clítico partitivo; e o auxiliar dos tempos compostos vai ser esserelêtre.
} 